\title{
MOTIVATION AND SATISFACTION TOWARDS TWO-YEAR VOCATIONAL DIPLOMA
}

\author{
Tanzir Masykar ${ }^{1}$, Febri Nurrahmi ${ }^{2 *}$ \\ ${ }^{1}$ Akademi Komunitas Negeri Aceh Barat \\ Jl. Alue Peunyareng, Ujong Tanoh Darat, Meureubo, Aceh Barat, Aceh 23681, Indonesia \\ ${ }^{2}$ Universitas Syiah Kuala \\ Jl. Teuku Nyak Arief No.441, Kopelma Darussalam, Syiah Kuala, Banda Aceh, Aceh 23111, \\ Indonesia
}

\begin{abstract}
Lack of students enrolling in diploma programs compared to what occurred Germany is a sign that Indonesian high school graduates are discouraged from enrolling in the program. Previous studies have mostly focused on the perception and expectation toward vocational high school, leaving motivation and satisfaction under-researched. This study aims to look at the motivation of students enrolling at the two-year diploma and how satisfied they are with the program. Factors contributing to their satisfaction would be presented accordingly. The study used a qualitative research approach with a case study design by examining current students at AKN Aceh Barat. A focus group discussion coupled with interview were employed to obtain the data and a total of 23 first year diploma students participated in the study. The study found that students were encouraged to enroll for the diploma program due to practical skill benefit, short durational advantage, and financial constraints of their families. They valued practical skills over theoretical knowledge and a short time of study over four years in college. The financial constraint also implies that most students enrolled in the program originate from financially unfortunate families. Most students have been satisfied with the program indicating that their initial motivation has been fulfilled. Factors contributing to their satisfaction include practical skills, theoretical knowledge, laboratory facilities, building infrastructure, and the number of students. They have been satisfied with the balance between practical skills and theoretical balance offered by the program yet felt the need for improvement in the other areas.
\end{abstract}

Keywords: motivation, satisfaction, vocational education, two-year diploma program, community college

How to cite: Masykar, T., \& Nurrahmi, F. (2020). Motivation and satisfaction towards twoyear vocational diploma. Jurnal Pendidikan Vokasi, 10(1), 10-21. doi:https://doi.org/10.21831/jpv.v10i1.30123 


\section{INTRODUCTION}

Law of Republic of Indonesia No. 12 of 2012 on Higher Education defines vocational education as a higher education institution that prepares students for jobs with certain applied expertise from diploma to applied undergraduate program. The institution can be further extended to offer applied master and doctoral degrees. The law also classifies the Indonesian higher education system into six categories: university, institute, higher education school, polytechnic, academy, and community academy. All these six categories can offer vocational education programs, while polytechnic, academy, and community academy can only provide vocational education. Community academy such as Akademi Komunitas Negeri (AKN) Aceh Barat being at the bottom of the Indonesian higher education system could only provide a two-year diploma.

AKN Aceh Barat is one of three regional campuses in West Aceh that have been nationalized by the Ministry of Research and Technology and Higher Education in 2014. The central government awarded national state status to three existing higher education institutions in West Aceh, namely Universitas Teuku Umar (UTU), Sekolah Tinggi Agama Islam Negeri (STAIN) Teungku Dirundeng, and AKN Aceh Barat. These three higher institutions have different focuses and purposes and do not seem to overlap over each other. While UTU and STAIN offer courses at the undergraduate level, AKN Aceh Barat focuses on the two-year diploma. UTU offers mainstream courses such as engineering, health, and also social sciences (Universitas Teuku Umar, 2019), and STAIN Dirundeng offers Islamic courses in Islamic education and social sciences (STAIN Dirundeng, 2019). On the other hand, AKN Aceh Barat, despite offering a diploma in engineering, aims to produce ready-to-work workforces for regional needs (AKN Aceh Barat, 2019). Therefore, its prospective students differ from the two higher education.

However, while the number of students applying for UTU has increased significantly and steadily for STAIN each year, AKN Aceh Barat failed to experience similar advantages. It is seen in the number of students applying for this vocational education in 2019. There were only 85 students enrolled at three engineering diplomas offered in AKN; most of whom received financial funding by the government through Bidikmisi scholarship. Such low interest to enroll in vocational education has been observed by Majid (2012) in his study suggesting the interest of more than $70 \%$ of respondents was generally categorized as medium.

Most classes at AKN Aceh Barat only has 20 students at most and 10 at least. Even though the size of the class seems ideal in European standards at around 15 students for small class and 22 students in the average (Chingos \& Whitehurst, 2011), it is far below what the non-diploma higher institutions in Indonesia have in their classes. Despite the hype of the current reshuffle in Indonesian cabinet and enthusiast of academic actors in vocational education (Utami, 2019), this phenomenon very much depicts how low community interest is in higher education diplomas. It is very different from Germany as the industry leader in vocational education in which almost half of its population (47.2\%) held a degree in vocational training (Spees, 2018).

A low number of students enrolled at the community academy must have something to do with the community perception and motivation to study for higher education. Previous studies have reported how the lack of vocational school's laboratory facilities (Hermanto et al., 2019) has lower student motivation to work well in class (Setiawati \& Sudira, 2015). The constraint in community perception and interest continue to prevail, as suggested by Saputri, Artana, and Haris (2013). Positive community perception toward diploma is crucial to attract stu-dents enrolling at vocational education. Parents in this regard play a central role in encouraging their children to study after high school to higher vocational education. Wulandari, Putro, and Rahmawati (2015) found that parents' perception of vocational high school influenced their children's decision to enroll at vocational high school. Students would tend to continue their next education based on parent consideration. Thus, promoting positive images of vocational education in the eye of the local community would help trigger community interest to let their children con-tinue their studies to vocational education. Some studies have tried investigating the community perception toward vocational education (Fatahillah \& Triyono, 2019; Saputri et al., 2013), but none has been done toward higher education. 
Previous studies on perception have produced mixed results under various themes such as perception (Sriwardani, 2011; Sunarko, 2009), expectation, interest, and image of vocational education (Wulandari et al., 2015). Meanwhile, Wulandari et al. (2015) and Saputri et al. (2013) used third-year secondary students to measure perception, Sunarko (2009) distributed his questionnaire to the third year vocational high school students. Sunarko (2009) was among the first to study the perception of vocational high schools. His study was a school self-evaluation to see how good the vocational high schools perceived by their students. In his study, 267 students from eight vocational high schools in Trenggalek were asked to fill a series of a questionnaire focusing on the institution, professionalism, competence, educational and training system, and graduates. He found that most students believed that the vocational high school has met their expectations in all off the six categories. His study is in line with Saputri et al. (2013) and Wulandari et al. (2015) in which students have positive images of vocational high schools.

Looking at a similar theme, student perception, Saputri et al. (2013) compared the perception of third-year students of two diferent secondary schools. Their findings seemed to contradict their initial belief that secondary students did not want to continue their studies to vocational high school (Saputri et al., 2013). They also argued that vocational high schools are often associated with low performer students and those who only want to work and do not intend to continue their studies to higher education levels. To their surprise, 204 students from both secondary schools perceived vocational high schools in positive ways. They found that all five categories they studied; function, study program, practical learning system, graduate outcomes, and the graduate prospect of vocational high school scores were relatively high. Though both schools gave slightly different values, the overall perception was the same. Similar to the study by Sunarko (2009), Saputri et al. (2013) focused only on vocational high schools, leaving the higher education diploma under-researched. Despite the fact that students have a positive image, the students' interest in studying at vocational education is unknown. It would be interesting to see how their perception eventually influenced their interest in studying at vocational high schools.

In the latter study, Wulandari et al. (2015) attempted to find how the interplay between parents' perception, student expectation, perception toward graduates affected student interest to study at vocational high schools. They found that both parent and student perceptions significantly influenced students' decisions over their study options. Expectation also played a central role in shaping their decisions whether to study at vocational high schools. They also measured parents' perceptions from evaluation and absorption indicators. However, they failed to provide any clear description of how they used both variables to indicate the parents' perception. They merely explained that parents first received information about a particular vocational high school and evaluated the information before making their decision whether to send their children to vocational high schools.

Current research by Fatahillah and Triyono (2019) also puts the weight on the importance of employability by studying the special job market perception among vocational high school graduates. They investigated how vocational high school graduates in Langsa perceived a special job market in four aspects; performance, role, service, and success of a special job market. Their study found that all 55 students participated in the study rated highly either for satisfied and very satisfied categories on all aspects and none rated for dissatisfied and quite dissatisfied. The positive rating given by students indicated that workability through a career center is extremely significant to vocational students. Such employability could be reached by ensuring the quality of graduates. The actual quality of vocational education should meet the students' expectations and perceptions. It should be further linked to the labor market in order to increase the employability of vocational students. A more recent study by Ishak and Sukirman (2019) also found a strong correlation between expectations and perception and the actual quality of vocational education.

Most previous studies have looked at how vocational education is perceived by either junior or senior high school students (Saputri et al., 2013; Sunarko, 2009), while other research focused on the perception of institution body outside vocational education also using high school students (Fatahillah \& Triyono, 2019). The research by Ishak and Sukirman mostly investigated the higher education students, yet mostly focused on expectation. Even though they used the term perception in their study, they failed to clearly distinguish between perception and reality, which is apparent in their abstract (Ishak \& Sukirman, 2019). 
Although there is a considerable amount of research on the perception of vocational education students, far less attention has been given to the motivation of students to choose to pursue a vocational degree. In fact, motivation is one of the most important factors that influence human behavior. It is defined as internal conditions that encourage individuals to achieve certain goals (Nursalam \& Efendi, 2008). Basically, the process of motivation is dynamic caused by the fundamental needs that encourage individuals to perform in order to fulfill the needs (Zainun, 2007). In addition, in the social phenomenology of Alfred Schütz, motivation has been categorized into in order to motive and because motives (Qamariah \& Sudrajat, 2013). The former is determined by individual expectations about the future or future orientation, while the latter refers to individual past experiences or past orientation (Qamariah \& Sudrajat, 2013). Moreover, Munandar (2001) argues that motivation will lead to satisfaction according to the extent that the determined goals are achieved. In this regard, their motivation to choose vocational education will determine their satisfaction. Hence, this study aims to look at what motivated the student of the two-year diploma program at vocational education in West Aceh enrolled for the program and to what extent they are satisfied with the program to fit in with their initial motives. Factors contributing to their satisfaction will be further elaborated. This topic emerges as an essential topic for the future development of this special education since it studied vocational students who are interested in vocational education and in the midst of experiencing the diploma education.

\section{RESEARCH METHOD}

The qualitative research approach was used in the study with a case study design. This study examined current students at AKN Aceh Barat. The current study used focused group discussion (FGD) and semi-structured interviews to gather the data. FGD is an appropriate method to obtain initial brainstorming data and generally catch participants' responses to a series of questions (Krueger \& Casey, 2002). It encourages participants to talk more about the topic with the help of another peers' idea. However, due to its communal activities, participants might tend to imitate popular responses closing the possibility of finding novel responses. In order to complement the FGD, most participants underwent semi-structured interviews. The interview provided the participants the ease to express their ideas and delivered private and distinctive answers. Its only drawback is that students might not have any ideas on how to respond to certain questions. Nevertheless, the interview's weakness has been complemented by FGD and vice versa.

A total of 23 students with the average ages of 19 years old participated in this study. Seven participants took part in FGD, while 16 students sat for interviews. All students whose responses are quoted would be assigned dummy names to refer to them in findings. Their assigned dummy names are typical Indonesian names such as Rio, Radi, and Nina.

The data obtained would be analyzed qualitatively following the model by Miles, Huberman, and Saldaña (2014). The analysis process consists of data collection, condensation and presentation. The process is further elaborated by Houghton, Murphy, Shaw, and Casey (2015), involving four stages, including extensive coding, pattern coding, distilling, and making propositions.

\section{RESULTS AND DISCUSSION}

Prior to inquiring about the core questions, all participants were asked background questions such as ages, type of school origin, work experience, and financial support in order to establish the demographic data. Each of them is elaborated as follows.

Out of the 23 participants taking part in the study, 18 of them are male while the rest are female. Most participants are aged between 18 and 19 years old, which is the typical age for Indonesian students enrolled for higher education. All participants are drawn from three different programs offered at the diploma in vocational education. Three students studied metal welding, seven studied concrete foundation and road paving, and 13 studied electrical network installation.

About $34 \%$ of the students had a background of vocational education as in their high school while the rest went to general high school. A total of 12 students came from general high school, eight students from vocational high schools, and three others originated from Islamic high school. 
More than half of the participants reported that they have worked prior to study at AKN Aceh Barat. The financial support for their studies also varied. Most students come from the medium-income families. More than $65 \%$ of the students received benefits from the government scholarship, while the rest got support from parents or close relatives. One student reported to be self-funded but was in the process of applying for the government scholarship for the next semester. The background data can be observed in Table 1 .

Table 1. Demographic Data

\begin{tabular}{lcc}
\hline & Demographic & Number \\
\hline Gender & Male & 18 \\
Age & Female & 5 \\
& $18-19$ & 16 \\
\multirow{3}{*}{ Department } & $20-21$ & 4 \\
& $22-23$ & 3 \\
Type of School Origin & Metal Welding & 3 \\
& Concrete Foundation and Road Paving & 7 \\
Work Experience & Electrical Network Installation & 13 \\
& General High School & 12 \\
Financial Support & Vocational High School & 8 \\
& Islamic High School & 3 \\
& Working & 13 \\
& Not Working & 10 \\
& Scholarship & 15 \\
& Parent & 5 \\
& Relative & 2 \\
\end{tabular}

\section{Motivation to Pursue Vocational Degree}

Participants conveyed various reasons as to why choosing the two-year diploma program over the undergraduate program. Meanwhile, student's motivation varied a lot, overall, their responses could be classified into three main categories, practical skills, durational advantage, and financial constraints. The discussion of motives is presented in descending order from the most to the least important motives. Each category will be presented with the main overview, followed by selected excerpts from the interview for illustration of what the interviewee expressed. Figure 1 depicts the overall motivation factors based on the demographic characteristics.

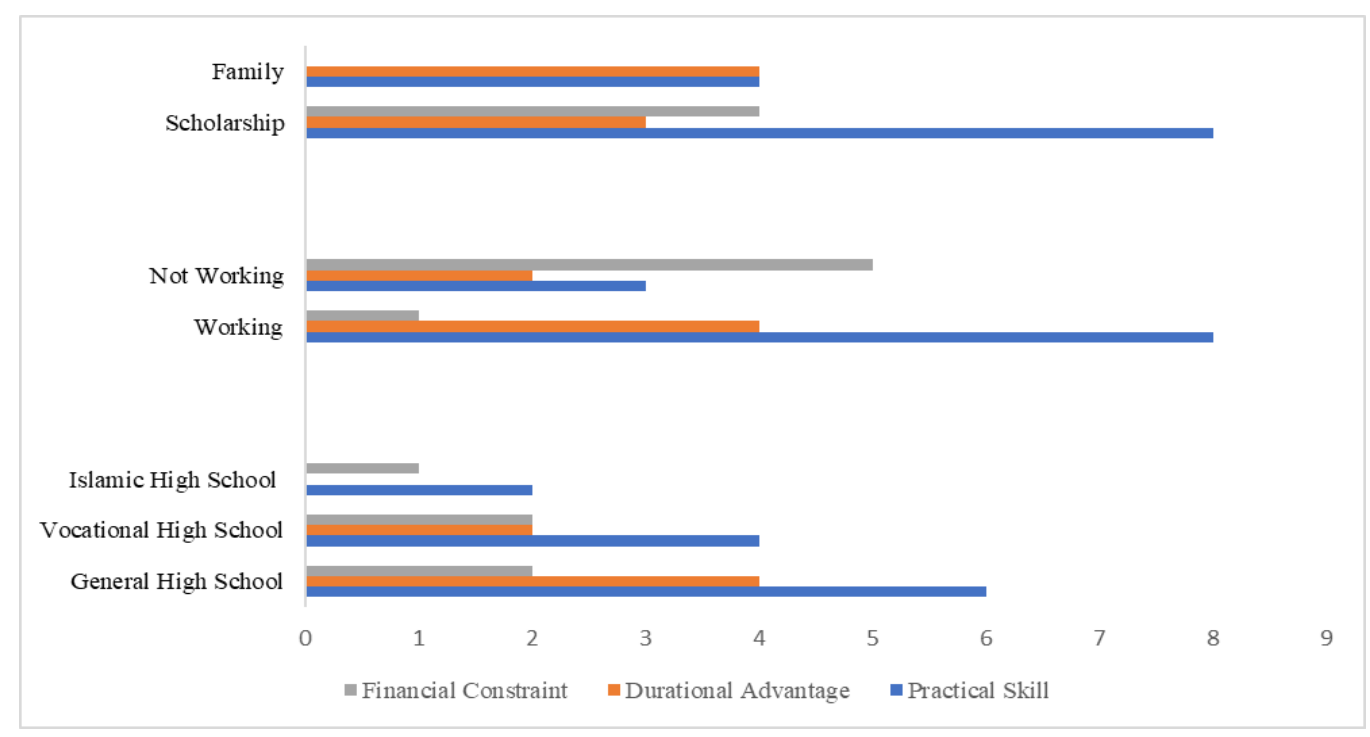

Figure 1. Motivation Factor by Demographic Characteristics 


\section{Practical Skill}

Practical skill defined here is the skill learned at an educational institution related to the use of tools in actual work. Almost all students argued that they chose diploma over undergraduate programs due to the practical curriculum offered in the diploma program. They believed that a vocational diploma would allocate most of its study time in a laboratory to equip students with applied skills. The diploma would provide a balance between theory and practice in its curriculum. Even general courses such as English have been tailored to English for vocational education, equipping students with practical English for engineering (Masykar, 2019). Such a need for curriculum integration has been coined by Arellano, Masykar, and Almulhim (2019). Getting their hand dirty with tools is much intriguing for these students compared to hours of lectures given in the undergraduate program. The skill they would get in vocational education could help them work for companies or open their own business in the future.

However, surprisingly few students argued that a vocational diploma will help them get jobs easier. It is in contrast to the data pro-vided by the National Centre for Vocational Education Research (NCVER) of Australia. The study found that getting a job is the main reason for people enrolling vocational education (Karmel \& Nguyen, 2006). A similar argument has been coined by Chareonwongsak (2018), citing the study of the Asian Development Bank. The followings are the excerpt from the participants on how the skill to be obtained in the vocational diploma is the major force of their decision to enroll in the program.

"I like working with tools instead of listening to theories. At the diploma, I would immediately be handed tools so that I could start working with them compared to theories", said Adi, who has been working in a paddy plant prior to enrolling at the vocational diploma. Another participant, Saidi, who owns a motorcycle cleaning service and funded his study with his own money, said, "Many undergraduate students do not have jobs after they finish their study. Here in diploma, I would learn skills and many companies are looking for skills nowadays."

Another participant, Rio, would go on and argued:

"Studying at university offers too many theories. My head could not grasp the theoretical framework. Diploma, on the other hand, offers practical skills. If I have skills, I would be able to make my own money once I graduated. I could work freelance installing electrical network or repair homeware electronics. Installing home electronics would earn me IDR 50K for each intersection installed."

Rio has worked as a construction and planta-tion laborer during high school to support his family. The 18-year-old received a benefit from the government scholarship for his study. The scholarship cover tuition fee and a less-than-adequate monthly stipend.

\section{Durational Advantage}

What we mean by durational advantage is benefit in terms of the length of study time between a two-year diploma over the traditional four-year undergraduate program. The duration of the study students have to spend on a two-year diploma is shorter than that at a university. At the vocational education, the students have choices to study ranging from two, three to four years, while universities require students to study at least four years to graduate. Vocational students see a shorter time at the diploma program as an advantage over an undergraduate program. They do not like to spend much time studying. They want to find work sooner and make money by cutting two years of study. Their responses could be observed in the following excerpts.

Rio, for example, wanted to work immediately after finishing his study. He does not like studying for a long period of time, like at the university. Bono, 21, who is two years older than Rio felt that his current age is the determining factor why he opted for the two-year diploma. He previously had studied at another diploma program in Aceh Barat Daya but failed to graduate because the institution went bankrupt just one semester before he graduated. He said:

"I am currently 21 years old. If I take the undergraduate program at a university, I would be 25 by the time I graduate. So, it is better for me to study in a two-year diploma program, which saved me another two years." 
He worried if he studied at a university, he would be too late to work. To put it in perspective, most Indonesian students graduate from university at the age of 22 years old, and by 25 years old, they should have a job as the source of income.

\section{Financial Constraints}

Financial constraint is defined as a monetary limitation faced by the participant to continue their study to higher education. In this study, financial constraints are divided into two types based on the source of tuition funding. Those who enrolled at the vocational program without scholarship considered as the lower tuition fee, which is only at IDR 600.000 as the reason to apply for the diploma. They argued that affordable tuition fee is one of the reasons they opted for vocational education. Students who received scholarships said that the scholarship is the reason for them to study in the diploma program. Some even argued that without the scholarship, they would not continue their study to a higher level of education. They felt better off working or study Islam. Some students come financially unfortunate families and could not afford to pay the tuition fees set by some universities. Associated cost during education is also out of reach for these low-income families. Therefore, it is reasonable for these students to search for a cheaper alternative to higher education offered by this unpopular institution. Their highlighted responses could be observed in the following excerpts from the interviews.

Rudi, an electrical engineer student, said:

"At first, my parents wanted me to study Islam in traditional Islamic boarding school. However, since I got a scholarship to study in AKN, my parents allowed me to continue the study. If I do not get the scholarship, my parent suggested me to study Islam at a boarding school."

Meanwhile, Nino, whose parent paid for his tuition fee, said:

"I have known this diploma program for a while, and it offers electrical engineering courses which absent in UTU. At first, I thought the tuition fee was expensive while, in fact, it is cheap. Therefore, I did not apply and became off-study for a year after high school."

Another interesting response worth mentioned was made by Nina. She said:

"My parents do not have money to support my study at the undergraduate level. Here, in the diploma, I get Bidikmisi (the government scholarship). I really wanted to study at a university, but my family could not afford it. Thus, instead of unemployed and do nothing at home, I decided to study a diploma instead."

Nina graduated from vocational high school in Meulaboh, majoring in agribusiness. She wanted to enroll at the University of Teuku Umar because the university offered agribusiness major but had to bury her hope due to financial constraints. The two-year diploma program she is currently in has met her hopes even though she is currently majoring in electrical engineering.

From the aforementioned underlying motives, the practical skills and the duration of study can be categorized into in order to motives. The expectation to gain more practical skills to their work in the future and their optimism to obtain their degree in a shorter time than university students are their future-oriented motivation. Moreover, the financial constraint can be classified as because motive. The lack of finance experienced by the participants has motivated them to choose to undertake vocational education over university as it offers lower tuition fees.

\section{Satisfaction toward Vocational Degree}

To contextualize the findings, it is worth mentioning that our current participants are all in the first semester of their study. The study was conducted at the end of their first semester. Thus, despite the fact that they are relatively new on the campus, they should have enough experience to establish their feeling toward the diploma program. When asked if the study experiences offered by the vocational education have lived up to their expectation before they enrolled, students demonstrated mixed answers. Their satisfactory level could be categorized into three levels, satisfied, unsatisfied, and in-between. The in-between is referred to the students who are satisfied with one 
aspect of the program yet felt the need for improvement in another aspect. Most of the students, 15 out of 23 students, reported that they were satisfied with the diploma program, while those who were not satisfied and in-between were five and three students respectively. The comparison of satisfaction level by demographic characteristics can be observed in Figure 2.

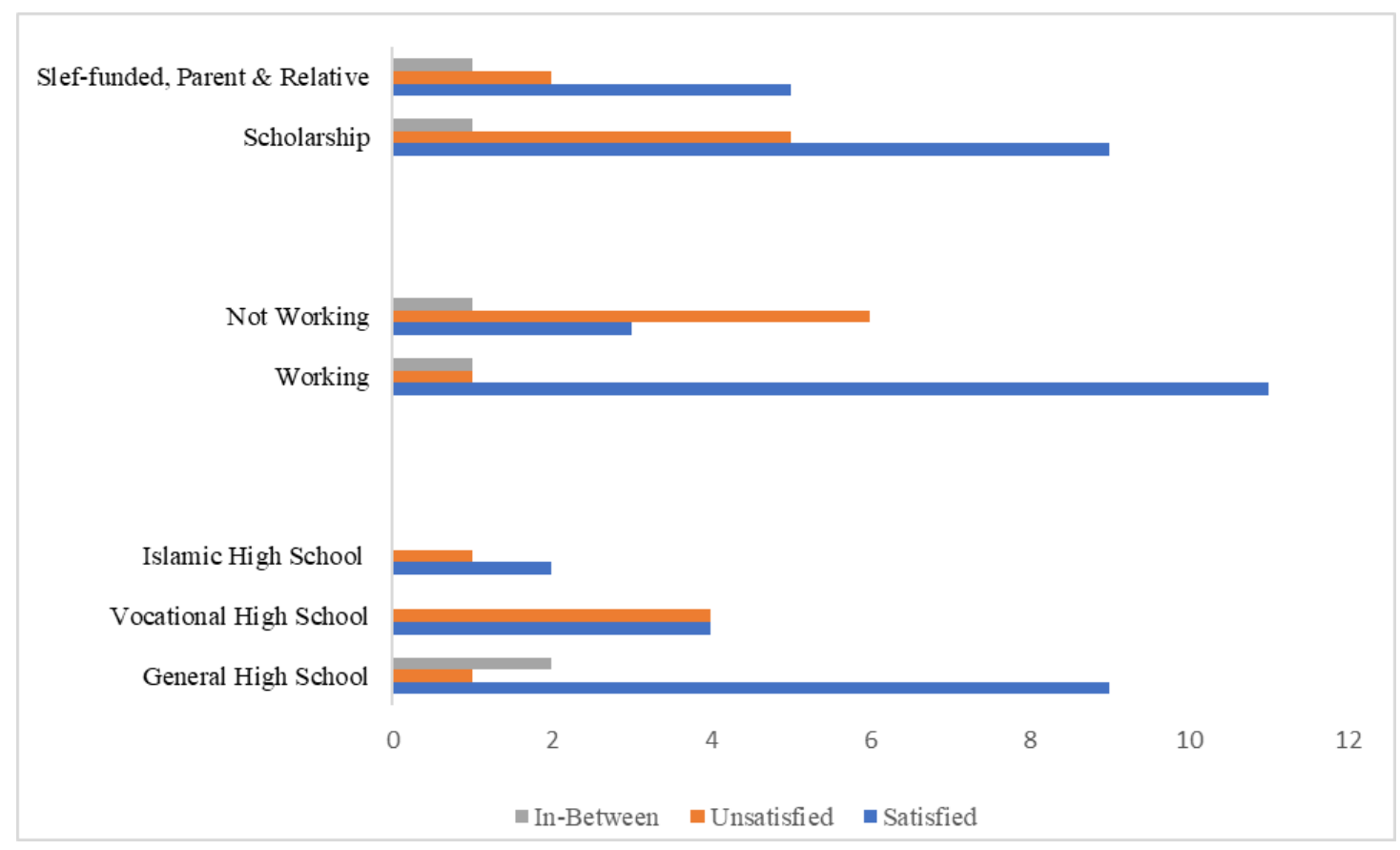

Figure 2. Satisfaction Level by Demographic Characteristics

Interestingly, the students whose high school background was vocational education had divided opinion on the quality provided in the current vocational diploma. Half students said that they were satisfied, while the other half felt that their high school was much better compared to the current diploma. The dissatisfied students coming from vocational high school contributed to $80 \%$ of the total number of dissatisfied students. Students with vocational background could compare the quality of the current program with their previous education while the students with general high school background do not have any experience to compare. Thus, they are pleased with the quality of the vocational diploma and only one student said that the education she got was not as expected. However, she did not refer to the educational quality provided but having to do with the mathematical calculation she had to endure in the program. Some of their responses could be observed as follows.

Nino, who is majoring at electrical installation argued that he has experienced changes in knowledge. He said:

"At my vocational high school, I only learned components, such as diode while here I learn it in more detail such as how the diode works. I am happy here because I get friends and knowledge. The facility is adequate, and, in fact, it is much more complete compared to the one I had in my previous vocational high school. In high school, we still used the broken tools, while here broken tools are not used.

Radi, on the other hand, made a strong dissatisfied argument and said, "My previous high school was much better. There, after theory, we immediately were given chances to apply it in practices. I felt this diploma taught me more theories. It is not what I expected. I learn drawings but discouraged." Radi is majoring in concrete and road paving engineering and the program offered different curriculum models than the other programs. While other programs integrated lad activities every week, the concrete and road paving diploma schedule laboratory work after three months of theoretical study. Thus, Radi could not observe immediate practice in his current diploma. 


\section{Factors Contributing to Students' Satisfaction}

The student's responses to satisfactory questions can be classified into five categories, practical skills, theoretical content, laboratory facilities, campus infrastructure, and student numbers. The distribution of factors by school origin can be observed in Figure 3.

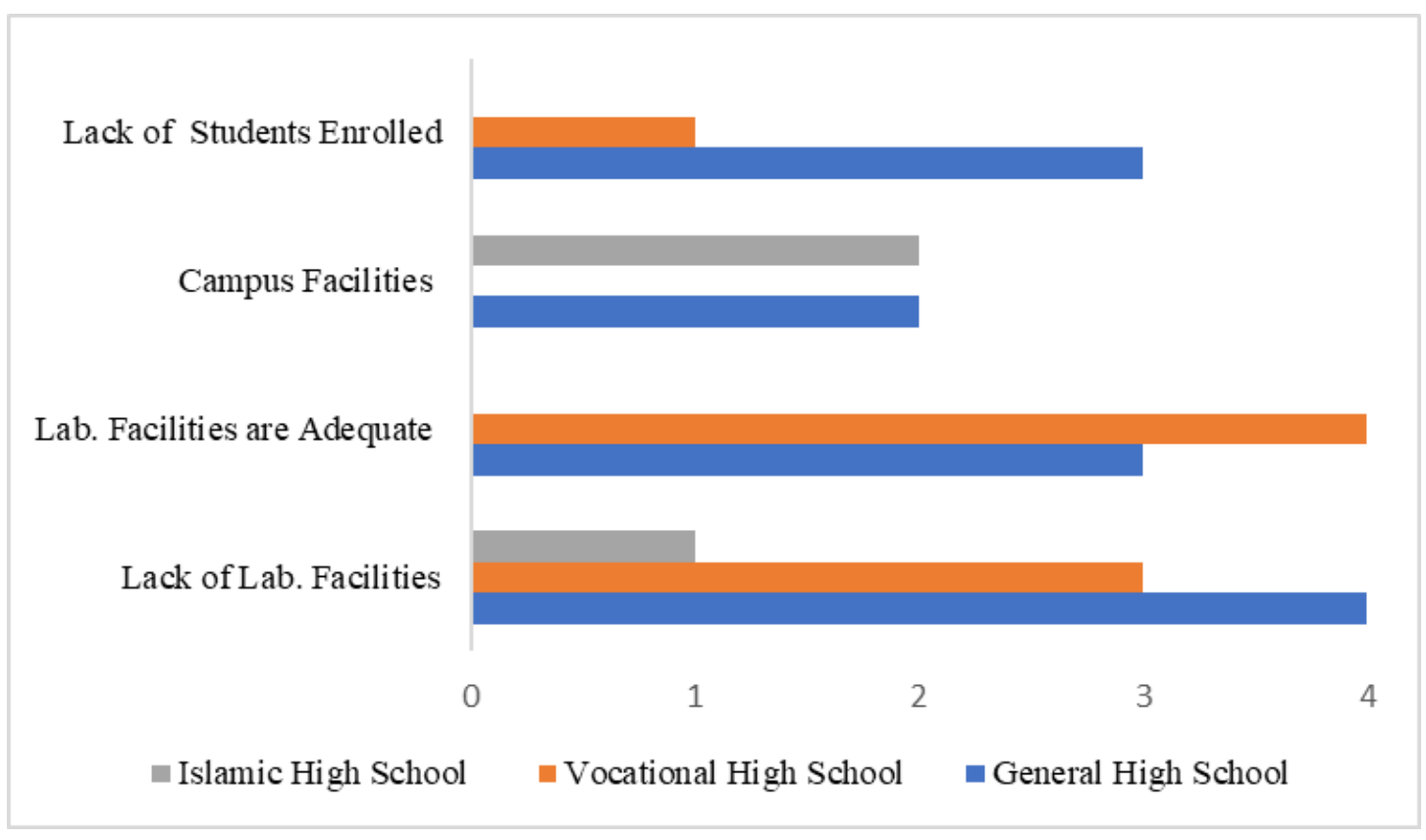

Figure 3. Factors Contributing to Motivation by School Origin

\section{Practical Skills}

Many students reported that they have learned some basic practical skills and are optimistic they will learn more in the next semester. However, some students felt that the diploma program does not give them enough practical skills compared to what they experienced in vocational high schools.

These students were mostly of vocational school origin. Students with non-vocational backgrounds felt that what they learn in the early semester is adequate and has met their expectations. They look forward to learning more skills in the next semester after observing what the seniors learn in the semesters to come. One student argued that the current diploma is lack of fieldwork. He felt that a field trip is important to give them real-life examples of how practical skills used at work. He came to this idea because he had studied in the diploma before. However, he did not finish the program since the institution went bankrupt.

\section{Theoretical Content}

In terms of theoretical content, students felt that the theory offered in the class had matched the practices they learned in the laboratory. This finding is in line with what is suggested by the Asian Development Bank research on the need for theoretical and practical complement in higher education institutions (Chareonwongsak, 2018). The knowledge they get is also much more indepth and detailed than what they learned in high school. They said that the content in the diploma is more focused compared to their vocational high schools. Students with general high school backgrounds also felt that they have learned many new things during their diploma degree. On the other hand, some students felt that the theoretical content is too much compared to vocational high schools. One student even claimed that the theoretical content outnumbered its practical content. Even though they felt so, they believed that it is acceptable in the first semester. Based on what they saw in senior classes, they are confident that in the next semester, they will learn more practical skills. 


\section{Laboratory Facilities}

Many students felt that laboratory facilities are inadequate. These are apparent from their argument that they have to share tools with friends when doing practical work in the laboratory. Sometimes they must wait for their friends to finish working with the tools. Even though some students felt that the lack of working tools hampered their chance to learn practical skills, others felt that working with friends is much better than working on tools alone. Lack of facilities has also been reported in the previous study on vocational high school by Hermanto et al. (2019). Further, Setiawati and Sudira (2015) argued the significance of facilities to motivate students in learning.

When working in a group on one tool, they can learn from their friends and help each other out. Those who felt each student should be given one tool believed that they could fully master the tools by having more time playing with it without having to wait. Interestingly, there is one student who said that the number of study time allocated to laboratory practice is overwhelming. They felt it inconvenient to be on campus from the morning to noon every weekday. His argument is discernable when we look at the number of times allocated by non-vocational higher education. In fact, this condition is what sets vocational education apart from other conventional education.

\section{Campus Infrastructure}

In addition to a lack of faculty laboratory, the students also felt that the in-class facility needs improvement. They complained about the broken classroom fans, unorganized, and dirty laboratories. One student also complained about the road to campus being muddy during rainy seasons and may cause an accident if left neglected.

\section{Number of Students}

Surprisingly to our initial belief, students felt that the lack of students is crucial for students during the study. They felt lonely and unmotivated because there are not many students who are studying at the vocational diploma. It basically contradicts the underlying presumptions that it is a privilege for the students to study in a small class. It is generally assumed that by studying in a small class, students would get more privatized knowledge, like the European education system (Chingos \& Whitehurst, 2011). In fact, they felt that the number of students in the classroom could motivate them to study and they can make a lot of friends. To put their answer in perspective, the average students in a class of each diploma program is 17 students.

According to the findings, it is apparent that the participants' satisfaction towards the vocational degree is highly determined by the motives to gain practical skills over merely theoretical knowledge. Another factor, such as laboratory facilities, is highly associated with practical skills. Their disappointment over the lack of tools in the laboratory is stemmed from their initial expectation to gain more practical skills at the vocational degree. These findings support the idea of Munandar (2001) that the extent to which the fulfillment of individual needs (motivation) is achieved can define the level of satisfaction.

\section{CONCLUSION}

This study found that students enrolling at the two-year diploma at the AKN Aceh Barat have distinctive motives and their motives have mainly been fulfilled at various degrees by the academy program. Factors contributing to a satisfactory level include practical skills, theoretical content, laboratory facilities, building infrastructure, and the number of students.

The diploma students are fully aware of the practical skills offered in the curriculum of the community college before enrolling. They believe that practical skills are very much needed in their future work, either by working for others or opening their own businesses. They saw the short duration of study in the diploma program as an advantage over the non-diploma program. Cutting two years of study of the conventional four years courses would give them the opportunity to experience work sooner and make their own money. Financial constraints of their family income may have prevented them from studying at higher education. Still, the community college, with its low tuition fee and full scholarship offers, has given them chances to change the course of their future 
fate. All of these have been in line with what the government initially intended by awarding state status to the academy.

Even though many students have been satisfied with the diploma program, some have felt that their motives have not been fulfilled. This finding needs to be seriously taken into account, considering those who had such opinions predominantly coming from vocational high schools. Even though some students admitted that the community college has managed to balance the practical skills and theoretical knowledge, some others still argued for the lack of practical skills taught. While the lack of laboratory facilities is reasonable as the reason for some students to be unsatisfied with the diploma, the low number of students enrolled at the college is an interesting factor for the students to feel discouraged during their study. Future studies should pay attention to the satisfaction of diploma students and their employability after graduates. The perception of the adjacent community toward a diploma should be researched as well to see how well non-diploma students perceive diploma programs. For the government to thrive in producing industrial workers, the policy and support in favor of the two-year diploma program should be prioritized. The designation of the special general directorate for vocational education under the ministry of education is a sign that the Indonesian government is serious about developing vocational education.

\section{REFERENCES}

AKN Aceh Barat. (2019). Akademi Komunitas Negeri Aceh Barat. https://aknacehbarat.ac.id

Arellano, R., Masykar, T., \& Almulhim, A. (2019). The rationale for a proposal for English language education: The experience of developing a curriculum to teach English for young learners. Proceedings of the 1st Aceh Global Conference (AGC 2018), 179-185. https://doi. org/10.2991/agc-18.2019.27

Chareonwongsak, K. (2018). Balancing theory with practice. University World News: The Global Window on Higher Education. https://www.universityworldnews.com/post.php?story= 20180523132915572

Chingos, M. M., \& Whitehurst, G. J. "Russ." (2011). Class size: What research says and what it means for state policy. Brookings. https://www.brookings.edu/research/class-size-whatresearch-says-and-what-it-means-for-state-policy/

Fatahillah, A., \& Triyono, M. B. (2019). Graduates' perception on the importance of special job market in state vocational high schools in Langsa City. Jurnal Pendidikan Vokasi, 9(2), 197206. https://doi.org/10.21831/jpv.v9i2.26361

Hermanto, F. Y., Sutirman, S., Hidayati, B., \& Sholikah, M. (2019). The need of practical teaching in vocational high school of Automation and Office Management Program. Jurnal Pendidikan Vokasi, 9(3), 238-248. https://doi.org/10.21831/jpv.v9i3.26734

Houghton, C., Murphy, K., Shaw, D., \& Casey, D. (2015). Qualitative case study data analysis: An example from practice. Nurse Researcher, 22(5), 8-12. https://doi.org/10.7748/nr.22.5.8. e1307

Ishak, A. A. A., \& Sukirman, A. S. (2019). Ekspektasi dan persepsi mahasiswa akuntansi terhadap kualitas pendidikan yang ditawarkan Politeknik Negeri Ujung Pandang melalui jalur mandiri. Journal of Applied Managerial Accounting, 3(1), 9-15.

Karmel, T., \& Nguyen, N. (2006). The value of completing a vocational education and training qualification. National Centre for Vocational Education Research.

Krueger, R. A., \& Casey, M. A. (2002). Designing and conducting focus group interviews. https:// www.eiu.edu/ihec/Krueger-FocusGroupInterviews.pdf

Law of Republic of Indonesia No. 12 of 2012 on Higher Education, (2012).

Majid, A. (2012). Faktor-faktor yang berpengaruh terhadap minat siswa SMP masuk SMK. Jurnal Pendidikan Vokasi, 2(3), 285-292. https://doi.org/10.21831/jpv.v2i3.1037 
Masykar, T. (2019). Analisa kebutuhan English for specific purpose untuk pendidikan vokasi. VOCATECH: Vocational Education and Technology Journal, 1(1), 47-50. https://doi.org/ 10.38038/vocatech.v1i0.9

Miles, M. B., Huberman, A. M., \& Saldaña, J. (2014). Qualitative data analysis: A methods sourcebook (3rd ed.). Sage.

Munandar, A. S. (2001). Psikologi industri dan organisasi. UI Press.

Nursalam, N., \& Efendi, F. (2008). Pendidikan dalam keperawatan. Salemba Medika.

Qamariah, R., \& Sudrajat, A. (2013). Motif keluarga dalam pemenuhan kebutuhan psikososial lansia. Jurnal Paradigma, 1(3), 1-7. https://jurnalmahasiswa.unesa.ac.id/index.php/ paradigma/article/view/4043/6558

Saputri, N. L. E., Artana, M., \& Haris, I. A. (2013). Persepsi siswa SMP kelas IX tentang sekolah menengah kejuruan (Studi kasus pada siswa kelas IX SMPN1 Sukawati dan SMPN1 Blahbatuh). Jurnal Pendidikan Ekonomi Undiksha, 3(1). https://doi.org/10.23887/jjpe.v3i1. 1240

Setiawati, L., \& Sudira, P. (2015). Faktor-faktor yang mempengaruhi prestasi belajar praktik kejuruan siswa SMK program studi Keahlian Teknik Komputer dan Informatika. Jurnal Pendidikan Vokasi, 5(3), 325-339. https://doi.org/10.21831/jpv.v5i3.6487

Spees, A.-C. (2018). Could Germany's vocational education and training system be a model for the U.S.? World Education News + Reviews. https://wenr.wes.org/2018/06/could-germanysvocational-education-and-training-system-be-a-model-for-the-u-s

Sriwardani, N. (2011). Persepsi mahasiswa terhadap perkembangan pendidikan vokasi di program pendidikan teknik mesin. Jurnal Pendidikan Vokasi, 1(1), 179-190. https://doi.org/10.21831/ jpv.v1i1.5813

STAIN Dirundeng. (2019). Sekolah Tinggi Agama Islam Negeri Teungku Dirundeng Meulaboh. https://staindirundeng.ac.id/

Sunarko, S. (2009). Persepsi siswa tentang pencitraan Sekolah Menengah Kejuruan (SMK) di Kabupaten Trenggalek. Teknologi Dan Kejuruan: Jurnal Teknologi, Kejuruan Dan Pengajarannya, 32(2), 177-186. https://doi.org/10.17977/tk.v32i2.3099

Universitas Teuku Umar. (2019). Universitas Teuku Umar. http://www.utu.ac.id/

Utami, L. D. (2019, December). Ainun Naim bicara soal program studi vokasi usai dilantik Nadiem Makarim jadi Sekjen Kemendikbud. Tribunnews.Com. https://www.tribunnews.com/ nasional/2019/12/16/ainun-naim-bicara-soal-program-studi-vokasi-usai-dilantik-nadiemmakarim-jadi-sekjen-kemendikbud

Wulandari, S. I., Putro, S. C., \& Rahmawati, Y. (2015). Pengaruh persepsi orang tua dan siswa terhadap minat masuk SMK. TEKNO, 23(1), 60-70. http://journal.um.ac.id/index.php/ tekno/article/view/5159/3915

Zainun, B. (2007). Manajemen dan motivasi. Balai Aksara. 